دراسات في آثار الوطن العربي 14

\title{
Representations of calves in some vignettes from the Book of the Dead.
}

Dr. dina mohamed ezz-eldeen ${ }^{\bullet}$ the Dead.

Representations of calves in some vignettes from the Book of The Ancient Egyptians showed special care and interest towards calves. They understood their importance in the Egyptian agrarianbased society in which the future of the herds depended largely on these young animals.

From the religious point of view, calves had their symbolic significance. Some funerary texts refer to a religious aspect that was given to the calf. In the Book of the Dead in particular, the calf appears in the vignettes of two Chapters. That of Chapter (1) is mainly concerned with the funerary procession and the ceremony of the Opening of the Mouth. Part of the vignette shows the cutting of a calf's foreleg.

The other Chapter (109) is entitled: Spell for knowing the Souls of the Easterners. Its scene was depicted on papyri as well as on tomb walls.

The research aims at shedding light upon these representations in order to interpret their funerary and religious significance.

- faculty of tourism and hotels - alexandria university - Thrown Mokhles your search and has not submitted for publishing a book conference 2012 